\title{
SIGNIFIKANSI RUMAH ADAT BAILEO SEBAGAI SIMBOL EKSISTENSI NEGERI DI AMBON
}

(The Significance of Baileo Traditional House As a Symbol of the State's Existence in Ambon)

\author{
Yulita Titik Sunarimahingsih; B Tyas Susanti; Bernadeta Resti Nurhayati \\ Unika Soegijapranata \\ Jalan Pawiyatan Luhur IV/1 Bendan, Semarang \\ yts@unika.ac.id
}

\begin{abstract}
Law No. 6 of 2014 concerning villages and the existence of regional autonomy, allows Ambon City to revive the States which are characteristic of the life order of the Ambonese people, with the authority to regulate the lives of its people according to customary law. It can be said that the State, which is in Ambon, is a customary law community unit that has territorial boundaries in one complete cosmic order (physical and metaphysical). The Baileo Traditional House is one of the custom symbols which is quite important in the life order of the indigenous peoples in Ambon City. This paper tries to examine the importance of the Baileo Traditional House as a symbol of the existence of the country. The results obtained from this study show that the role of the Baileo Traditional House is not only as a place associated with traditional processions or events. The Baileo Traditional House has a central role in the order of community life, both basic and related to customary values. The Baileo Traditional House is also the center of the democratic life of indigenous peoples
\end{abstract}

Keywords: Baileo, Negeri, Custom Symbols.

\begin{abstract}
Abstrak
Undang-Undang no 6 tahun 2014 tentang desa dan adanya otonomi daerah, memungkinkan Kota Ambon menghidupkan kembali Negeri-Negeri yang menjadi ciri khas tata kehidupan masyarakat Ambon, dengan otoritas untuk mengatur kehidupan masyarakatnya sesuai hukum adat. Dapat dikatakan bahwa Negeri, yang ada di Ambon, merupakan merupakan kesatuan masyarakat hukum adat yang memiliki batas-batas wilayah dalam satu tatanan kosmos yang utuh (fisik dan metafisik). Rumah Adat Baileo merupakan salah satu simbol adat yang cukup penting dalam tata kehidupan masyarakat adat Negeri di Kota Ambon. Tulisan ini mencoba mengkaji arti penting dari Rumah Adat Baileo sebagai simbol eksistensi Negeri. Hasil yang di peroleh dari telaah ini memperlihatkan bahwa peran Rumah Adat Baileo tidak hanya sebagai tempat yang perkaitan dengan prosesi atau peristiwa adat. Rumah Adat Baileo memiliki peran sentral dalam tata kehidupan masyarakat baik yang sifatnya mendasar maupun yang berkait dengan nilai-nilai adat. Rumah Adat Baileo juga menjadi pusat kehidupan demokrasi masyarakat adat.
\end{abstract}

Kata kunci: Baileo, Negeri, Simbol Adat 


\section{Pendahuluan}

\section{Latar belakang}

Kota Ambon selain dikenal dengan julukan city of the music, juga dikenal dengan kota yang meliliki banyak Raja. Sebagian besar wilayah Ambon sejak dahulu terdiri atas Negeri, dimana adat istiadat hidup, diakui, dihormati, dipertahankan, dipatuhi, dan dilaksanakan (Watloli, 2019). Tepatnya Kota Ambon terdiri atas 20 kelurahan, 3 desa dan 22 Negeri. Negeri adalah sebutan untuk desa adat yang dipimpin oleh seorang raja dan memiliki hukum adat sendiri, namun tetap tunduk pada aturan pemerintah.

Pada tahun 1979 dengan diterbikannya Undang-Undang Desa No 5 tahun 1979 tentang pemerintahan desa, terjadi penyeragaman tentang tata pemerintahan desa dan bersifat sentralistik. Status dan aturan Negeri harus mengikuti aturan yang sudah ditetapkan oleh pemerintah. Dengan penyamaan status ini, raja tidak memiliki kekuasaan atas Negeri. Raja sama dengan kepala desa, dan dipilih sesuai dengan aturan yang ada. Pada tahun 2014, lahir undangundang no 6 tahun 2014 tentang desa, (dan adanya otonomi daerah) memberikan keleluasaan desa untuk mengatur rumah tangganya sendiri.dan memberikan kesempatan kepada desa untuk memunculkan ciri khasnya. Kondisi ini disikapi oleh kota Ambon dengan menghidupkan kembali Negeri-Negeri sebagai cirikhas tata kehidupan masyarakat Ambon. Negeri mempunyai otoritas untuk mengatur tata kehidupan masyarakatnya sesuai dengan hukum adat yang berlaku, namun tetap dalam kesatuan dengan pemerintah Ambon.

Dapat dikatakan bahwa Negeri, yang ada di Ambon, merupakan merupakan kesatuan masyarakat hukum adat yang memiliki batas-batas wilayah dalam satu tatanan kosmos yang utuh (fisik dan metafisik). Secara fisik, Negeri di Kota Ambon merupakan kumpulan dari soa, dan soa merupakan kumpulan dari matarumah atau marga. Secara metafisik, Negeri merupakan sebuah wujud eksistensi adat yang terbangun dalam persekutuan dan keutuhan adat dengan alam semesta serta bagaimana berperilaku terhadapnya; dimana didalamnya terdapat nilai-nilai, keyakinan, ikatan solidaritas, dan simbolsimbol adat.

Menurut Koentjaraningrat (1986), dalam praktek kebudayaan, masyarakat menggunakan konsep kolektifitas, dimana dalam kolektifitas tercermin adanya interaksi antar manusia dan mereka membangun berbagai simbol dan aktifitas untuk mempertahankan kolektifitas tersebut.

Diantara simbol yang dibangun oleh masyarakat Negeri di Ambon adalah Baileo, Batu Pamali, Batu Teon dan upacara-upacara adat. Baileo merupakan salah satu simbol penting yang menanda adanya suatu Negeri. Pada saat ini banyak Baileo Negeri di Ambon yang sudah tidak ada lagi.

\section{Tujuan}

Tujuan dari tulisan ini adalah mengungkap arti penting dari Rumah Adat Baileo bagi eksistensi sebuah Negeri di kota Ambon

\section{Metode}

Dalam tulisan ini analisis terhadap permasalahan yang ada dilakukan dengan pendekatan deskriptif analitis, yang bertujuan untuk melihat peran baileo dalam kehidupan masyarakat adat di Ambon dan dalam konteks eksistensi baileo sebagai simbol adat negeri. Untuk menemukan makna dasar dari baileo digunakan deskripsi kualitatif yang didasarkan dari literatur dan tutur dari tokoh adat Negeri setempat..

\section{Kajian Teori}

\section{Pengertian}

\section{Negeri}

Negeri adalah suatu persekutuan masyarakat adat berdasarkan territorial genealogis (Ajawaila, 2000). Sejarah pembentukan Negeri di Ambon bermula 
dari Pulau Seram, dimana mereka membentuk kelompok dalam Uli. Sistem pengelompokan ini kemudian dibawa oleh para migran ke pulau-pulau kecil, salah satunya adalah pulau Ambon. Mereka mendarat di pantai ambon dan kemudian berdiam dipegunungan untuk menghindari perompak. Menurut Chauvel (dalam Ajawaila, 2000), pada masa penguasaan Belanda, mereka dipaksa untuk pindah ke daerah pantai untuk memudahkan pengontrolan pada perdagangan cengkeh, dan dibentuklah negeri-negeri berdasarkan segreasi agama, yaitu negeri islam (salam) dan negeri kristen (sarani). Negeri-negeri ini memiliki batas teritori yang jelas. Lokasi yang mula-mula mereka diami di pegunungan dinamakan sebagai Negeri Lama yang mereka anggap sebagai Negeri Leluhur.

Negeri merupakan kumpulan dari beberapa soa dan soa ada yang terdiri dari 1 atau lebih mataruma. Hubungan sosial masyarakat berbasis pada kekerabatan mataruma.

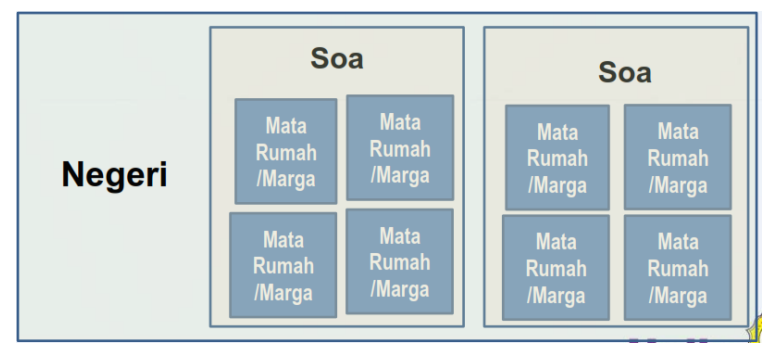

Gambar 1: Pembagian Negeri berdasar Soa

Baileo

Baileo berasal dari bahasa melayu balai yang berarti balai bersama atau lebih tepatnya sebagai tempat bermusyawarah bagi masyarakat adat terdiri dari tetua adat dan masyarakat, dalam mencari solusi atau pemecahan atas permasalahan yang ada. Selain sebagai tempat musyawarah, baileo juga berfungsi untuk menyimpan bendabenda pusaka dan tempat dilakukannya upacara adat. Dengan demikian dapat dikatakan terdapat dua peran utama dalam baileo (Huwae, 2012) yaitu:

a. sebagai tempat pemersatu dan demokrasi b. sepagai pusat upacara adat dalam suatu komunitas. Dan juga sebagai sarana komunikasi dengan roh-roh nenek moyang.

\section{Signifikansi Nilai Budaya}

Signifikansi atau nilai penting budaya merupakan aspek penting dalam memahami apakah produk budaya baik yang tangible maupun non tangible dalam mengkaji apakah produk tersebut merupakan simbol adat dalam suatu masyarakat adat. Signifikansi budaya juga menjadi aspek penting dalam kegiatan pelestarian simbol adat tersebut. Untuk memahami signifikansi budaya, dijelaskan dalam Burra Charter pasal 6.1 bahwa:

"Signifikansi budaya sebuah tempat dan hal-hal lain yang berpengaruh pada masa depannya paling baik dipahami melalui serangkaian tahap pengumpulan dan analisis informasi sebelum membuat keputusan. Hal pertama adalah memahami signifikansi budayanya, kemudian membuat kebijakan dan akhirnya mengelola tempat tersebut sesuai dengan kebijakan yang ditetapkan"

Dari pasal 6.1 Burra Charter jelas bahwa ada tahap pengumpulan dan analisis informasi untuk bisa sampai pada satu kesimpulan akhir tentang signifikansi nilai.

Australian Herritage Commission (1999) juga menunjukkan bagaimana pentingnya pemahaman terhadap nilai dalam proses konservasi:

"...a key principles in heritage conservation is the need to understand the heritage importance or significance of a place before making a decision about how to manage it....the ways in which a place isnimportant areits heritage values"

Ketika komunitas atau masyarakat itu dapat mengidentifikasi nilai-nilai penting yang melekat pada warisan atau benda budayanya, maka mereka akan bisa menghargai masa lalunya dan sekaligus memperkuat ikatannya dengan masa depan. Ketika warisan budaya itu lenyap, maka akan lenyap bagian dari sejarah yang sudah diukir oleh nenek moyang mereka, 
lenyap pula nilai-nilai yang melekat pada warisan budaya tersebut. Beberapa Alasan yang memperkuat untuk penelusuran signifikansi budaya ini antara lain karena:

1. warisan budaya yang ada dalam masyarakat tersebut sangat berkaitan dengan masa lalu mereka, yang mengingatkan mereka akan sesuatu moment atau peristiwa yang special dalam kehidupan mereka

2. Warisan budaya yang merupakan bagian dari identitas suatu lokasi

Ada banyak cara untuk menggali signifikansi nilai budaya. Table berikut adalah tahapan yang ditawarkan oleh Australian Herritage Commission

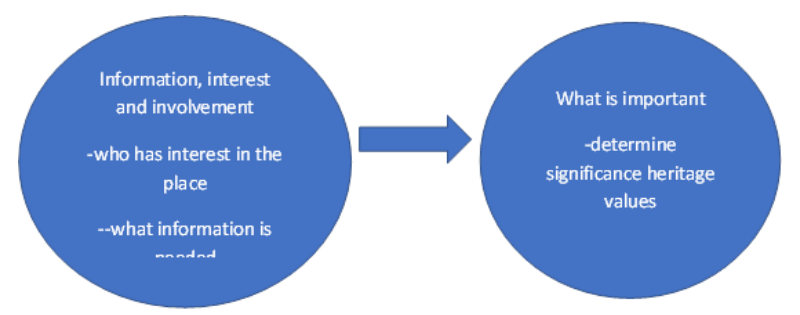

Gambar 2: Tahapan untuk menggali signifikansi nilai budaya

\section{Sumber: Australian Heritage Commission, 1999}

Pada tahapan tersebut, tahap awal adalah tahap untuk menggali nilai yang melekat pada warisan budaya. Menggali informasi nilai dilakukan dengan mengidentifikasi siapa saja yang memiliki kepentingan akan warisan budaya tersebut. Identifikasi ini bisa dikatakan juga sebagai identifikasi stakeholder yang terkait dengan warisan budaya tersebut . Tahap selanjutnya adalah menentukan mana yang menjadi nilai utama atau nilai yang signifikan dari warisan budaya tersebut sehingga dapat ditemukan keistimewaan dari warisan budaya tersebut.

\section{Hasil Penelitian Dan Pembahasan}

Peninggalan-peninggalan budaya Maluku tidak dapat dipisahkan dari sejarah dan bentuk struktur masyarakat adat. . Masyarakat Adat di Maluku terjadi melalui beberapa tahap pertumbuhan (Hetharion, dkk, 2012):

Tahap pertama, tahap paling dasar adalah mata ruma sebagai perikatan keluarga batih ditandai dengan kesamaan fam, dan biasanya memiliki pusat kosmos secara eksklusif berupa rumah tua dan batu teung.

- Tahap kedua, adalah terbentuknya persekutuan soa. Soa bisa terdiri dari satu matarumah atau kumpulan dari beberapa matarumah yang dikepalai oleh kepala soa. Dan memiliki batu teung soa

Tahap ketiga adalah terbentuknya hena atau aman, yaitu perkumpulan dari soa-soa. Dalam hena simbolsimbol utama seperti baileo dan batu pamali telah terbangun. Bentuk asli dari baileo itu biasanya berupa pelataran yang ditandai dengan batubatu daam berbagai ukuran dan bentuk. Masing-masing batu mempunyai fungsi dan peran yang dikaitkan dengan jabatan adat dalam hena, seperti misalnya batu raja, batu kapitang, batu marinyo, batu tempat duduk kepala soa dan sebagainya. Susunan batu-batu ini berfungsi untuk musyawarah para pejabat adat untuk membicarakan permasalahan adat

Tahap keempat, adalah terbentuk nya Negeri. Pada dasarnya negeri adat adalah hena. Istilah Negeri adalah wujud karena pengaruh kololonial Belanda terhadap penaklukan henahena. Untuk mempermudah monopoli perdagangan, Mereka dipaksa pindah dari gunung dan membuat permukiman di tempat baru di sekitar pantai. Kemudian permukimam lama (di gunung) mereka namakan negeri Lama. Di Negeri yang baru mereka membuat atau memindahkan simbol adat baileo berupa rumah adat dan batu pamali. Selanjutnya, simbolsimbol adat seperti negeri lama, baileo, batu pamali, batu teong, dsb 
menjadi hamparan kosmos di lingkungan sosial masyarakat adat, mengintegrasikan masyarakat adat dalam satu ikatan yang bersifat permanen.

Bentukan Baileo yang berupa rumah adat, tidak lepas dari sejarah terbentuknya Negeri. Menurut mitos, penduduk asli masyarakat ambon berasal dari Nunusaku sebuah gunung dari Pulau Seram (Ajawaila, 2000). Ada 3 kelompok yaitu kelompok ulisiwa, ulilima, dan kelompok uliasa (duyvendak, dalam Ajawaila 2000). Menurut beberapa pustaka,diyakini kelompok yang datang ke pulau Ambon adalah dari kelompok ulisiwa dan ulilima, yang kemudian di kenal dendgan patasiwa dan patalima. Pada perkembangannya pada masa kolonial Belanda, Kelompok patasiwa merupakan negeri-negeri Kristen dan patalima merupan negeri-negeri Islam. Patasiwa dan patalima membawa implikasi pada bentukan rumah adat baileo. Rumah Adat Baileu Patasiwa berupa rumah panggung, sedangkan Baileo Patalima menapak pada tanah.

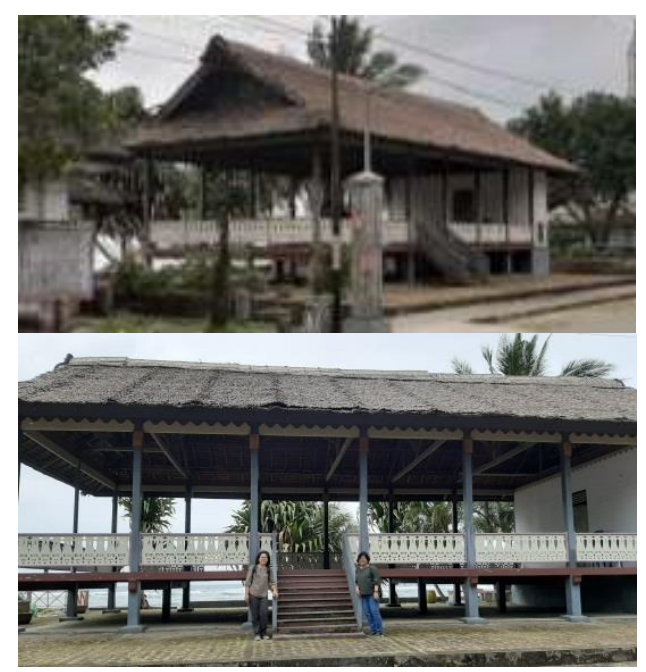

Gambar 3: Baileo Negeri Hutumuri (Baileo Patasiwa)

Sumber: Dokumen Peneliti, 2019

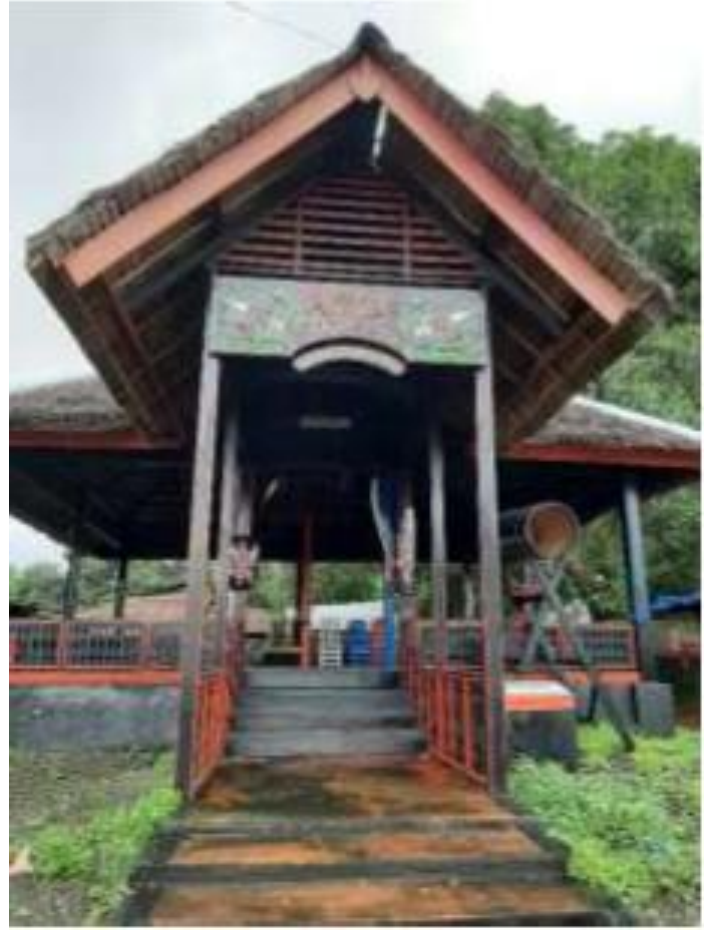

Gambar 4: Kakihang: Baileo Negeri Laha (Baileo Patalima)

\section{Sumber: Dokumen Peneliti, 2019}

Karena diyakini bahwa didalam baileo juga terjadi komunikasi dengan leluhur, maka Baileo dibuat terbuka tanpa dinding. Dengan bentuk ini diyakini arwah nenek moyang akan ikut melihat apa yang dibicarakan dan di musyawarahkan di dalam baileo. Namun demikian, bentuk terbuka ini secara fungsional selain memberikan kesempatan kepada masyarakat yang bukan pejabat adat juga dapat mendengarkan dan menyaksikan apa yang dibicarakan dan dilakukan didalam baileo, sehingga pengambilan keputusan penting yang berkait dengan adat, masyarakat juga dapat mengetahui. Selain untuk memberi kesempatan masyarakat mengikuti jalannya musyawarah, bentuk terbuka ini juga menjadikan baileo menjadi terang dan sirkulasi udara juga baik.

\section{Peran dan Fungsi Baileo bagi masyarakat adat di Ambon}

Menurut penuturan Bapak Daniel (Tetua Adat Negeri Latuhalat) fungsi dan peran Baileo bagi masyarakat adat adalah: 
a. Sebagai tempat berkumpul untuk membicarakan hal-hal yang stategis pembangunan dan nilainilai adat.

b. Merupakan suatu tempat dimana nilai-nilai adat dipertahankan, dilestarikan dan menghidupkan nilai-nilai adat.

c. Sebagai pertemuan-pertemuan tentang adat, seperti Pasawari Adat, Pelantikan Raja, dan Musyawarah-Musyawarah yang menyangkut adat.

Pada perkembangannya, peran baileo tidak hanya unuk hal-hal uang berkaitan dengan adat, namun juga digunakan untuk musyawarah berkait dengan pendidikan, sosial, kesehatan dan hal mendasar lain yang berkaitan dengan kehidupan masyarakat yang mendasar dan melibatkan seluruh masyarakat. Perkembangan fungsi ini tidak hanya terjadi di Negeri Latuhalat, namun juga terjadi di Negeri Halong, dan beberapa Negeri. Pengembangan peran atau fungsi baileo dilakukan setelah menerima masukan dari masyarakat adat untuk merubah paradigma baileo sebagai simbol adat yang hanya digunakan pada peristiwaperiswa tertentu tetapi menjadi sarana musyawarah sebagai inti dasar dari baileo dan juga adaptasi terhadap lingkungan tanpa menghilangkan nilai-nilai dan proses adat yang ada.

Dapat dikatakan peran Rumah Adat Baileo tidak hanya berkait dengan permasalahan adat saja tetapi lebih pada peran musyawarah bersama didalam kehidupan bermasyarakat untuk mencapai suatu keharmonisan dalam hidup. Mereka menghargai keputusan yang dihasilkan oleh hasil musyawarah yang dilakukan dalam baileo, karena mereka meyakini bahwa nenek moyang mereka juga hadir dan menyaksikan musyawarah tersebut. Dengan demikian, baileo memiliki peran yang cukup sentral dalam negeri.

Sebagai tempat musyawarah dan sekaligus simbol adat negeri yang cukup penting, masyarakat menghormati dan menghargai dengan ikut merawat dan menjaga baileo tesebut melalui empati. Hal

TERAKREDITASI : 36/E/KPT/2019

ISSN cetak 1410-6094 | ISSN online 2460-6367 ini seperti diungkap oleh salah satu narasumber dari Negeri Halong (wakil ketua Saniri Negeri Halong):

“..Kita harus menjaganya, karena kalau tidak dilakukan maka para leluhur kita bisa saja akan datang melalui mimpi kita dan menegur kita untuk membersihkan baileo tersebut. Bukan itu saja pernah terjadi suatu hari kita melakukan perbaikan terhadap Baileo dengan melibatkan pekerja dari luar kemudian sementara dalam proses pekerjaan masih berlangsung mereka mengumpulkan sampah-sampah dari baileo itu berupa kayu kayu dari pembongkaran tersebut tiba-tiba kayu-kayu dari pembongkaran yang kita tumpukkan menghilang diangkat orang memakai mobil dan truk setelah kita bertanya kepada pekerja mereka mengatakan bahwa tadi ada pihak kantor desa yang mengangkatnya. Kemudian kita melakukan penylidikan ke semua pihak kantor dan kita Tanya keperja mereka bilang tidak ada wajah yang sama seperti pihak kantor yang mengangkat kayu tersebut. Maka usut punya usut mereka adalah Leluhur kita sendiri yang mereka tidak mau melihat baileo kita itu kotor.'

\section{Penutup}

\section{Kesimpulan}

Berdasar dari kajian di atas dapat disimpulkan bahwa

1. Rumah Adat Baileo memiliki peran yang cukup penting dalam tatanan Negeri. Hal ini ditunjukkan dengan peran dan fungsinya sebagai sarana berjalannya kehidupan sosial masyarakat adat secara demokratis yang didasarkan pada nilai-nilai/norma adat yang ada

2. Melihat fungsi dan peran Rumah Adat Baileo merupakan salah satu simbol Adat yang sangat penting

3. Baileo menjadi penciri berjalannya kehidupan masyarakat adat Negeri

\section{Saran}

Perlunya upaya mempertahankan Rumah Adat Baileo terutama perannya

Tesa Arsitektur Volume 18| Nomor 2 | 2020 
sebagai pengikat masyarakat adat dan sebagai simbol eksistensi Negeri.

\section{Ucapan Terimakasih}

Tulisan ini merupakan bagian dari penelitian tentang "Konservasi Benda Budaya Simbol Adat Sebagai Penguatan Eksistensi Negeri Dalam Pembangunan Paska Konflik Di Ambon", yang didanai oleh kemenristekdikti melalui skim Penelitian Dasar Unggulan Perguruan Tinggi (PDUPT). Untuk itu, penulis mengucapkan terimakasih kepada Kemenristekdikti untuk kesempatan ini.

\section{Daftar Pustaka}

Ajawaila, Yacob W. 2000. Orang Ambon dan Perubahan Kebudayaan. Jurnal Antropologi Indonesia Th XXIV No 61 Jan-Apr 2000 e-ISSN 1693-6086 print ISSN 1693-167X

Hetharion, Betty DS, dkk. 2012. Peranan Batu Pamali Dalam Kehidupan Masyarakat Adat di Maluku. Balai Pelestarian Nilai Budaya Ambon Kementrian Pendidikan dan Kebudayaan. Cetakan 1 2012. Ambon

Huwae, Andrew. 2012. Baileu: Kajian Tentang Bentuk Manifestasi Fisik Dari Masyarakat Adat Di Kecamatan Pulau Saparua. Kapata Arkeologi Vol. 8 Nomor 1 / Juli 2012. Balai Arkeologi Ambon

Koentjaraningrat. 1986. Pengantar IImu Antropologi. Aksara Baru. Jakarta

Watloli, 2019, Kosmologi Masyarakat Ambon, Paper dipresentasikan di FGD Konservasi Benda Budaya Simbol Adat Dalam Pembangunan Kota Ambon, 19 Agustus 2019

---.2000. The Burra Charter: The Australia ICOMOS Charter for Places of Cultural Significance 1999. Published by Australia ICOMOS Incorporated 2000

---1999. Environmental Reform (Consequential Provisions) Act 1999. 